Article

\title{
Resilience in Practice: Responding to the Refugee Crisis in Turkey, Jordan, and Lebanon
}

\author{
Rosanne Anholt \\ Department of Political Science and Public Administration, Vrije Universiteit Amsterdam, 1081 HV Amsterdam, \\ The Netherlands; E-Mail: r.m.anholt@vu.nl
}

Submitted: 31 March 2020 | Accepted: 10 July 2020 | Published: 10 December 2020

\begin{abstract}
Little is known about how the idea of 'resilience' translates into practice. It has nonetheless emerged as a dominant theme in the governance of crises, such as political instability, armed conflict, terrorism, and large-scale refugee movements. This study draws on interviews with humanitarian and development practitioners in Turkey, Jordan, and Lebanon working under the Regional Refugee and Resilience Plan to explore how resilience is interpreted and translated on the ground. Results suggest that resilience is translated as the economic self-reliance of refugees, and the capacity for crisis management of refugee-hosting states, enacted through 'localization' and strengthening the 'humanitarian-development nexus.' The prominence of the political and economic context and the power relations between crisis response actors that it generates reveals the limits of what a buzzword like resilience can achieve on the ground. The findings highlight the need for researchers, policymakers, and practitioners to engage in continuous critical reflection on whether the ways in which resilience policies and programmes are implemented actually improve the ability of systems and vulnerable populations to recover from crisis, as well as on the validity of the assumptions and interpretations on which such policies and programmes are built.
\end{abstract}

\section{Keywords}

crisis governance; development; humanitarianism; resilience

\section{Issue}

This article is part of the issue "The Politics of Disaster Governance" edited by Dorothea Hilhorst (Erasmus University Rotterdam, The Netherlands), Kees Boersma (Vrije Universiteit Amsterdam, The Netherlands) and Emmanuel Raju (University of Copenhagen, Denmark).

(C) 2020 by the author; licensee Cogitatio (Lisbon, Portugal). This article is licensed under a Creative Commons Attribution 4.0 International License (CC BY).

\section{Introduction}

'Resilience' has emerged as a dominant theme in the governance of crises such as political instability, armed conflict, terrorism, and large-scale refugee movements. Notwithstanding its adoption by the United Nations (UN) agencies, donors, governments, and (international) non-governmental organizations ([I]NGOs), resilience has been criticized for its buzzword-like qualities. Its ambiguity, in particular, has provoked questions about the concept's usefulness for practice (Manyena, 2006) as it risks becoming "an empty signifier that can easily be filled with any meaning to justify any specific goal" (Weichselgartner \& Kelman, 2014, p. 249).
Despite these concerns, buzzwords often provide a sense that "in the midst of all the uncertainties of the day, international institutions are working together for the good, and that they have now got the story right and are really going to make a difference" (Cornwall \& Brock, 2005 , p. 1043). Against the backdrop of protracted crises across many regions of the world and unprecedented numbers of refugees, 'resilience' may promise the ability "to anticipate and tolerate disturbances... without collapse, to withstand shocks, and to rebuild as necessary" (Lentzos \& Rose, 2009, p. 243). Little is known, however, about how this translates into practice.

The objective of this study is to explore how the concept of resilience is interpreted and translated into 
practice. It draws on 40 interviews with 47 humanitarian and development practitioners in Turkey, Jordan, and Lebanon working under the Regional Refugee and Resilience Plan (3RP). This crisis response platform assists countries surrounding Syria with managing the influx of large numbers of Syrian refugees-including through what practitioners have termed 'resiliencebuilding.' Bringing together some 270 humanitarian and development actors, including governments, UN agencies, national and international NGOs (3RP, 2019), the 3RP constitutes "one of the biggest humanitarian operations ever realized by the UN" (Dionigi, 2016, p. 27).

I argue that in practice, the concept of 'resilience' becomes imbued with particular-even narrowmeanings contingent on crisis response actors' interpretations of the context, which in turn determine how resilience, as a capacity for recovery, is 'built.' To what extent resilience policies and programmes can achieve results on the ground, however, ultimately depends on the political and economic context and the power relations it generates between crisis response actors. In this way, the results provide empirical evidence for the political nature of crisis governance, which, rather than a technocratic exercise, is "shaped by the people, institutions and history of the context in which crises happen" (Hilhorst, 2013, p. 5).

The article unfolds as follows. The next section offers an overview of the literature on resilience (Section 2). Next, I propose a conceptual framework for understanding the translation of resilience into practice, based on theories of translation that allow for recognition of, and sensitivity to, the various dimensions of power and politics at play in crisis governance (Section 3 ), followed by a brief overview of methods (Section 4). Subsequently, the $3 R P$ is described in more detail (Section 5), followed by the empirical material (Section 6). The article concludes with a discussion of the results and the implications for research, policy, and practice (Sections 7 and 8).

\section{What is Resilience?}

Resilience is not a new concept. It stems from the Latin resilire, which means to 'leap' or 'jump back.' Throughout history, resilience has been used, on the one hand, to describe the quality of materials to bend without breaking (Bourbeau, 2018). On the other hand, it referred to human character and behaviour: A resilient person possessed the trait of fickleness and would cancel or go back on their word (Alexander, 2013). From the mid-19th century onwards, however, resilience started to be used in the sense of fortitude after a misfortune. A US military expedition to the east coast of Japan, which had been struck by the Ansei-Tokai earthquake of 1854 , identified "a resiliency in the Japanese character which spoke well for their energy. They [the Japanese] did not sit down and weep over their misfortunes, but, like men, went to work, seemingly but little dispirited" (Hawks, 1856, pp. 511-512; see also Alexander, 2013).
The 1970s witnessed a proliferation of theories and research on resilience in psychology and ecology. Within psychology, the turn to resilience marked a shift in the focus on vulnerability and deficiency to protective factors and adaptive capacities (Masten, 2013, 2018). Within ecology, resilience was coined as a measure of the ability of ecological systems to persist despite change and disturbance and to reorganize while maintaining their functions (Holling, 1973; Walker, Holling, Carpenter, \& Kinzig, 2004). Intellectual exchange between ecologists and risk management scholars has likely facilitated the uptake of resilience in the field of the latter (Clark \& Swain, 1975). In the 1980 s, resilience was championed as a strategy to mitigate the effects of a crisis-being both better and cheaper than either anticipation or prevention (Wildavsky, 1988). Resilience was subsequently picked up by disaster scholars and practitioners, becoming an integral component of international disaster risk reduction frameworks (Comfort, Boin, \& Demchak, 2010).

In the first half of the 2010s, resilience emerged as a central axiom of humanitarian and development aid, reflected in its adoption by major donors, including Britain's Department for International Development, the United States Agency for International Development, and the European Commission. In 2016, moreover, the concept was placed at the heart of the European Global Strategy for Foreign and Security Policy, sparking an impassioned, critical debate about the meaning of resilience and the repercussions for those at the receiving end of resilience policies. These critiques can be organized around three main arguments: First, because resilience manifests in response to a crisis, i.e., after the event, it assumes not only the inevitability of crises but also the insignificance of interrogating the (structural) causes of crises (e.g., Evans \& Reid, 2013, 2014); second, resilience tends to responsibilize individuals, communities, and states for their resilience-de facto also responsibilizing them for their vulnerability (e.g., Ilcan \& Rygiel, 2015; O'Malley, 2010); and third, resilience may be considered a neoliberal strategy to outsource security to crisis-affected individuals and communities, taking responsibility off the shoulders of states or the international community (e.g., Chandler \& Reid, 2016; Duffield, 2012).

Concerned in particular with the ontologies and epistemologies that underpin the global turn to resilience and with the interrogating resilience discourses in policy, critical resilience scholarship has thus far not systematically engaged with how resilience policies are interpreted and, in turn, implemented by practitioners. An exception is a study by Aldunce, Beilin, Howden, and Handmer (2015), which identifies different understandings of resilience among natural disaster management practitioners, and how these subsequently generate different practices. Moreover, Scott-Smith (2018) argues that whereas critical scholars have interpreted resilience as a depoliticizing concept, humanitarian practitioners have instead denounced it for politicizing their work. This 
paradox points towards the importance of examining practitioners' views on policy concepts and how these shape programme design and implementation. The next section offers a theoretical framework through which the implementation of 'resilience' can be conceptualized.

\section{A Politics of Translation}

The various constructivist turns in the study of policy and politics attest to the growing interest in, and the perceived importance of, the role of ideas and discourse in policy and political processes (Fischer \& Gottweis, 2012). The role of ideas in policy implementation has nonetheless been neglected, mirrored by a lack of attention to ideas in implementation research (Béland \& Ridde, 2016). Exploring how the policy idea of resilience is put into a set of programmes and operational practices necessarily engages with this nexus between ideas and implementation-for which the concept of 'translation' may provide a useful theoretical framework.

Weisser, Bollig, Doevenspeck, and Müller-Mahn (2014) argue that "people do not act according to the script of a single global idea, but that they appropriate or modify parts of that script and also invent new ones" (p. 112). Instead, "as policy travels across languages, sites and scales, it is produced, assembled, enacted and populated differently" (Clarke, Bainton, Lendvai, \& Stubbs, 2015, p. 60). In other words, as ideas travelnot just across the boundaries of academic disciplines and policy areas or across geographical borders, but also from the global to the local and from policy to practice-they are modified as a result of translation processes (Weisser et al., 2014). Rather than being simply implemented, therefore, "policies are interpreted and 'translated"' (Braun, Maguire, \& Ball, 2010, p. 549). "Translation" may be defined as:

[T] he process of modification of policy ideas and the creation of new meanings and designs in the process of the cross-jurisdictional travel of policy ideas. Translation allows viewing the 'global' in 'local,' and 'local' in 'global,' with regard to the adoption, implementation and travel of ideas and enables simultaneous consideration of ideas, objects and interests. (Mukhtarov, 2014, p. 76)

Importantly, a translation perspective draws attention to three interrelated aspects of policy implementation: the transformation of ideas, the agentic capacities of 'translators,' and the role of context.

First, a translation perspective acknowledges that the process of translating a global policy idea to a particular locality "always involves transformation" (Czarniawska \& Sevón, 2005, p. 8). Translation indicates that a policy idea:

Is made to mean something in its new context. Policy is never a singular entity: it is put together- or assembled-from a variety of elements that are always in the process of being re-assembled in new, often surprising ways. (Clarke et al., 2015, p. 10)

Ideas are "edited, translated, and cobbled together from various sources for idiosyncratic use" (Powell, Gammal, \& Simard, 2005, p. 237). This means that 'resilience,' translated to the operational context of the 3RP, will be imbued with meanings different from those attributed to the more abstract notion of resilience in global policy frameworks.

Second, translation processes involve 'translators': actors who actively interpret and transform ideas in accordance with the context within which they operate. Traditional perspectives have tried to capture the travel of ideas in terms of policy 'transfer' or 'diffusion,' which imply "a central broadcast point and wide reception with rather passive receivers" (Powell et al., 2005, p. 233). Ideas, however, "do not travel by themselves, nor are they pushed around by forces such as regionalisation, neoliberalism, or globalisation" (Mukhtarov, 2014, p. 76). A translation perspective instead underlines the agentic capacities of translators, and unlike much policy implementation research, leaves behind assumptions of rationality and intentionality (Mukhtarov, 2014). Translators "always act according to existing interests and always operate within certain power relations, [therefore] they are likely to transform concepts according to very particular intellectual, epistemological, political, and historical requirements" (Neumann \& Nünning, 2012, p. 9).

Third, Braun, Maguire, and Ball (2010) note that "[p]utting policies into practice is a creative, sophisticated and complex process that is always also located in a particular context and place" (p. 549, emphasis added). Translation is a process of recontextualization (Braun, Ball, Maguire, \& Hoskins, 2011) that is "characterized by selective appropriations and translations according to historical and local circumstances" (Neumann \& Tygstrup, 2009, p. 1). The outcome of translation processes is thus contingent on the various political, economic, and social incentives that exist within the particular context-and are meaningful only within that context (Mukhtarov, 2014; Weisser et al., 2014). Because translation always serves an interest (Freeman, 2009), "some things are made visible while others are hidden or erased" (Clarke et al., 2015, p. 49). This enables a politics of translation (Clarke et al., 2015) that allows for exploring the role of power relations in how policy ideas translate into practice.

As ideas, because they travel from the global to the local and from policy to practice, a politics of translation perspective calls attention to idea transformation, the role of actors, and the impact of contextual factors. These aspects provide the analytical tools to explore the context-specific meanings of a global policy buzzword like resilience, and how it is translated into practice by various actors working under the banner of the 3RP in Turkey, Lebanon, and Jordan. 


\section{Methods}

Forty semi-structured interviews of approximately one hour were held with 47 humanitarian and development practitioners between October 2018 and June 2019 in Gaziantep, Amman, and Beirut, as well as over Skype. Relevant organizations were initially identified from 3RP documentation, including the regional strategic overview and the 3RP country chapters. Potential respondents were subsequently identified from organizations' websites, policy documents and publications, or from country-specific online civil society platforms, such as the Lebanese website www.daleel-madani.org. They were approached via email or social media for a face-toface or Skype interview.

Respondents represent 32 different organizations. Nine (28\%) are Turkish, Jordanian, or Lebanese civil society organizations operating at the national level (referred to as national CSOs), or organizations established by Syrians in Turkey (referred to as Syrian-led CSOs). Twentythree $(72 \%)$ are international organizations, with headquarters outside Turkey, Jordan, or Lebanon. These included 15 INGOs, five UN agencies, and three different governmental organizations, including a diplomatic mission, a donor agency, and a network organization. At least 23 respondents (49\%) were Turkish, Lebanese, Jordanian, or Syrian nationals-the remainder were international expats. Seventeen respondents were female (36\%), 30 were male (64\%). Nearly all respondents held management positions in the area of programmes, coordination, or partnerships. For some, their work focused exclusively on the national (Turkish, Lebanese, or Jordanian) context, others (also) worked at the regional level, i.e., across the different 3RP countries, or on cross-border operations into Syria. They were, therefore, familiar with the national and regional policy discussions and processes, as well as their organizations' programmes and impact thereof on the ground. Respondents were thus in a good position to talk about how resilience translates into practice. Due to the political nature of the crisis, respondents remain anonymous.

Respondents were asked about the crisis response, their understanding of resilience, and what resilience means within an operational context. In addition, they were asked about the roles of and the relationships between the different actors involved in crisis response, including the Turkish, Jordanian, and Lebanese governments, UN agencies, INGOs, and Turkish, Jordanian, Lebanese, and Syrian-led CSOs.

Interviews were audio-recorded and transcribed verbatim. Written transcripts were subjected to a thematic analysis to "identify or examine the underlying ideas, assumptions, and conceptualizations-and ideologiesthat are theorized as shaping or informing the semantic content of the data" (Braun \& Clarke, 2006, p. 85). This included familiarization with the data (e.g., reading and re-reading interview transcripts) and coding using Atlas.ti. Themes were constructed by clustering codes into meaningful patterns and refined through an iterative examination of the themes in relation to each other and the research question. Together, the themes tell "a story that is based on, and about, the data, that makes sense of the patterning and diversity of meaning" (Terry, Hayfield, Clarke, \& Braun, 2017, p. 30).

\section{Setting the Scene: The Regional Refugee and Resilience Plan}

One year after pro-democracy protests in the southern Syrian town of Dara'a spread across the country triggering a violent crackdown from the government, the UN High Commissioner for Refugees (UNHCR) had registered 40,000 refugees crossing Syria's borders into Jordan, Lebanon, Turkey, and Iraq (United Nations High Commissioner for Refugees [UNHCR], 2012). In response, the agency launched the first Regional Response Plan (RRP) in March 2012 to address "the needs for protection and assistance of refugees fleeing from the Syrian Arab Republic" (UNHCR, 2012, p. 4). The years that followed not only witnessed Syria spiral into a complex multi-layered conflict drawing in a growing number of non-state armed groups and international actors, but also saw refugee-hosting countries grapple with the rapidly increasing numbers of refugees. By late 2014, UNHCR had registered 4,270,000 Syrian refugees in Turkey, Jordan, Lebanon, Iraq, and Egypt (3RP, 2014).

Recognizing the impact of the Syria crisis on the region, the UN Development Programme (UNDP) introduced a 'resilience-based' development response to the Syria crisis in 2014 (Gonzalez, 2016). Whereas resilience discourses were largely absent in UNHCR's RRPs, UNDP argued that "[w]here situations and conditions have stabilised, and people and communities are coping and beginning to recover, development assistance that builds resilience can accelerate their recovery and enhance their capacities to prosper independently" (UNDP, 2014, p. 16).

The 3RP was launched in December 2014, combining UNHCR's short-term humanitarian emergency response with UNDP's longer-term development approach, in what is known among practitioners as the 'humanitariandevelopment nexus' (see also Hilhorst, 2018). The New Way of Working-one of the outcome documents of the 2016 World Humanitarian Summit-describes the nexus as humanitarian and development actors working towards collective outcomes, based on their comparative advantage in terms of capacity and expertise (United Nations Office for the Coordination of Humanitarian Affairs, 2017).

The 3RP resilience component addresses "the resilience, stabilization and development needs of impacted and vulnerable communities and aims to strengthen the capacities of national actors to lead the crisis response" (3RP, 2019, p. 20). It defines resilience as "the ability of individuals, households, communities and institutions to anticipate, withstand, recover and trans- 
form from shocks and crises" (3RP, 2019, p. 9). As central tenets of a 'resilience approach,' the plan specifically refers to the need to "increase self-reliance and selfsufficiency of vulnerable populations through marketbased skills training and employability, income generation opportunities and entrepreneurship programmes" (3RP, 2019, p. 9) and to "work together with government, national and local institutions to strengthen existing service delivery systems, to identify vulnerabilities and address needs and risks...and improve capacities to manage future shocks" (3RP, 2019, p. 9). It does not, however, clarify how these activities lead to resilience as defined in the 3RP.

\section{Results}

\subsection{Understanding Resilience in the $3 R P$ Context}

First, in line with 3RP discourse and across the different contexts, 'resilience' was above all understood in terms of self-reliance. As one respondent explained, "building resilience is about creating a conducive environment for refugees, host communities, government, municipalities-all stakeholders - to take care of themselves without or with less external support, in a sustainable way" (interview 13-J13, network organization). This was seen to apply to both individuals and the state, as another respondent pointed out:

The resilience of beneficiaries is the capacity of a person to take care of their basic needs, and the capacity to cope positively with difficult situations. Then there is the organizational perspective, of NGOs, of national government. This doesn't mean building the resilience of each individual in the country, but of the national structure of the country. (interview 6-J6, INGO)

More specifically, system resilience was understood as the capacity of the state to continue responding to the crisis without breaking under the pressure of the additional demands of a large refugee population for public services and resources. This generated a focus on strengthening the political, economic, and social systems and structures that exist at local and national level. Individual resilience was more narrowly understood as economic self-reliance, with a focus on access to employment-particularly of refugees residing in urban areas. In the words of one respondent: "you can't have resilience if you can't have the ability to work" (interview 10-J10, INGO). Another respondent in Turkey explained:

From the field, we hear that most refugees are thinking about staying here. Also, the situation in Syria is not settled down...we don't know if a political solution will come. So, we need to increase refugees' employability and increase their self-reliance. So that when they are here in Turkey, they are working and generating an income to survive. (interview 37-T12, UN agency)

Second, these context-specific understandings of resilience were rationalized based on respondents' understanding of the context as a protracted crisis occurring in middle-income countries. Respondents recognized that the unpredictability of the situation in Syria demands thinking beyond the traditional shortterm time horizons of emergency aid, and towards longer-term solutions, regardless of whether Turkey, Jordan, and Lebanon accept the possibility of refugees' long-term presence, let alone employment. According to one respondent:

Resilience means durable, long-term solutions. It includes empowerment, community-based protection, it includes improving the capacity of the state institutions-all these are components of resilience. The main idea of resilience is long-term solutions. Without resilience, all solutions are temporary, meaning a waste of money, waste of resources, and waste of time. (interview 39-T14, Turkish CSO)

Respondents felt that 'resilience-building' was not only necessary because of the protracted nature of the crisis, but also because, unlike the more traditional contexts of humanitarian and development work, Turkey, Jordan, and Lebanon are middle-income countries. As a respondent in Jordan observed:

I don't think anyone would deny the reality that you have a very strong structure. It's a middle-income country, there are qualified professionals, there is foreign investment....You have political and bureaucratic mechanisms, there is an administration.... mean, it's a country with a strong state, it's not as if you were implementing in a failed state like Somalia. (interview 13-J13, INGO)

This has required a different way of working, because, as another respondent admitted: "Obviously, a lot of us worked in countries where there's almost no state, and we're used to create these parallel systems because there is no government system that can do it" (interview 26-T1, UN agency). In the context of a middleincome country, 'resilience-building,' in terms of tapping into and strengthening the existing political, economic, and social systems and infrastructures, makes more sense and is more sustainable than setting up parallel structures which only disappear once international actors leave.

Third, respondents identified two primary practices of 'resilience-building': the first occurring through the strengthening of the 'humanitarian-development nexus,' and the second through 'localization.'

Respondents largely understood the humanitariandevelopment nexus as a combination of, on the one 
hand, humanitarian assistance for refugees (as per the traditional UNHCR mandate), and, on the other hand, development assistance for refugee-hosting states and vulnerable host communities. Especially the dual focus on refugees and vulnerable host communities was seen as a necessary strategy to prevent potential social tensions resulting from selective aid provision:

It's a vulnerability approach, which is logical. If you're living in northern Jordan and suddenly your village has doubled its population, and all the Syrians get humanitarian aid...cash assistance...that doesn't work. Everyone realized quite early on that if we don't also provide assistance to host communities, things will go wrong. (interview 9-J9, diplomatic mission)

The need to connect humanitarian aid and development assistance was furthermore rooted in respondents' understanding of crises as complex, where the emergency, early recovery and development phases overlap rather than forming an orderly sequence. Donors seem reluctant to accept this reality, however, as a respondent in Lebanon described:

Donors were turning a blind eye to the refugees in informal settlements who still have nothing. They're indebting themselves, they have no jobs, and they're just living by whatever the international community provides. Donors kind of decided that this can't happen anymore, this can't be there anymore, this only happens at the beginning of a crisis, emergency should be over now, we should focus on other things. They would say "we're six years into the crisis, how the heck can you still have this?" (interview 16-L3, INGO)

Another challenge to realizing the humanitariandevelopment nexus may be the relationship between UNHCR and UNDP (see also Zetter, 2020). In the words of one respondent: "The cultural differences between the organizations, it's just profound" (interview 5-J5, UN agency).

Respondents interpreted localization broadly as the involvement of Turkish, Jordanian, and Lebanese actors. At the level of state actors, localization meant ownership of the national government and authorities at the local level, e.g., municipalities, over the crisis response. Respondents perceived these actors as having the ultimate responsibility for responding to the needs of their population-including refugees-necessitating their position in 'the driver's seat.' At the level of nonstate state actors, localization meant specific practices within INGOs, such as employing Turkish, Jordanian, Lebanese, or Syrian staff and partnering with Turkish, Jordanian, Lebanese, or Syrian-led CSOs. Moreover, localization also involved 'building the capacity' of such partner organizations with a view to an eventual handover. These 'localization strategies' have led to varying degrees of involvement of Turkish, Jordanian, and Lebanese state and non-state actors, which is discussed in more detail in the next sub-section.

Summing up, the concept of resilience is largely understood in terms of self-reliance, which can be 'built' through strengthening the humanitarian-development nexus and through localization. What this looks like in practice, however, depends on the political, economic, and social context of the three countries. Although a systematic country comparison is beyond the scope of this article, the next section discusses prominent examples from each context.

\subsection{The Contextual Limits to 'Building Resilience'}

\subsubsection{Turkey}

Respondents characterized Turkey, above all, as a strong state with a capacity to lead on the response. As one respondent asserted: "Unlike Jordan and Lebanon, Turkey is a player in its own right" (interview 20-J14, INGO). Initially, Turkey's Disaster and Emergency Management Presidency (AFAD) was responsible for overseeing the crisis response, a role that was later handed over to the Directorate General of Migration Management. Some respondents observed that few international actors were used to working in a strong government context:

The UN has experience working with very weak governments. They are used to managing everything, getting all the information they need. And they thought they could work like that in Turkey. In Jordan, the UN agencies are managing everything, the cash programmes, collecting iris scan data...you can't do that in Turkey. (interview 32-T7, Turkish CSO)

At the same time, suspicion, expulsion, and detainment of staff have proven Turkey a challenging work environment especially for INGOs (see also Boztaş, 2019; Cupolo, 2017; Mellen \& Lynch, 2017). Respondents pointed out that Turkey wished to limit western donors' influence, accusing international organizations of lacking the proper registration or of financing terrorist organizations. Nonetheless, the Turkish government was seen as understanding of the need for 'durable solutions,' engaging with, in particular, the Turkish private sector to provide refugee employment.

Typical for Turkey was the rise and professionalization of Syrian-led NGOs (organizations established by Syrians in Turkey) engaged in both the refugee response within Turkey and cross-border operations into Syria. Respondents saw their involvement as an important way to localize the crisis response, but also noted challenges, in particular with regards to the funding system. Specifically, in the absence of a direct link between institutional donors and Syrian-led (or otherwise Turkish, Jordanian, and Lebanese) organizations, funding is channelled through INGOs and typically limited to project- 
specific costs-excluding costs related to staff salaries, rent, and administration (see also Field, 2016). Donor requirements remain another stumbling block, as one respondent explains:

One of the conditions of ECHO [European Civil Protection and Humanitarian Aid Operations] is to be registered in Europe for five years. So, as a local organization, it's not possible to get funding from ECHO. There are also requirements with regards to capacity....And we have been working on our capacity since we registered in Turkey in 2014, but even then, we're still a new organization. You can't expect us to live up to the standards of Oxfam or Save the Children. (interview 38-T13, Syrian-led NGO)

Another respondent shared an example whereby their local partner received a direct grant, but also put this into perspective: "It's good...but it's also too late. After eight years, we're talking about one partner who got directly funded by an institutional donor" (interview 27-T2, INGO).

The examples from the Turkish context show how national governments may secure state-level localization by limiting the humanitarian space for international actors. At the same time, the funding structures of the international aid system limit the possibilities for localization at the level of non-state actors. These findings challenge the concept of localization and the extent to which it can 'build resilience.'

\subsubsection{Jordan}

From the start of the crisis, the Jordanian government was involved in decision-making, planning, and coordination. It appointed the Ministry of Planning and International Cooperation (MoPIC) as the lead agency and established a secretariat and information management system. Nonetheless, respondents expressed their frustration with the Jordanian crisis response system in terms of its bureaucracy, lack of capacity, and instances of corruption. In particular, respondents complained about the time it took the government to grant project approval-in some extreme cases taking over six months to a year. This was dependent on the relationship between INGOs and line ministries, as one respondent illustrated:

I had a good relationship with MoPIC, my projects were often approved within a month. But I remember other organizations had a hellish relationship with them...government is like "I don't like you, you can wait." Why? In the end, I'm sorry to say, it's personal. (interview 4-J4, INGO)

Project approval also depends on how aid is divided between Syrian and Jordanian beneficiaries. Respondents explained that under the 3RP protection and resilience pillars, projects must target at least 30\% and $70 \%$ vulnerable Jordanians, respectively. In this way, Jordan ensures that both humanitarian and development assistance benefits its own citizens. As with previous waves of Palestinian and Iraqi refugees, several authors have noted Jordan's tendency to leverage its position as a refugee-hosting state to increase access to international aid (Arar, 2017; Kelberer, 2017; Tsourapas, 2019). Respondents did not seem to find this particularly problematic, however, justifying this strategy on the basis of Jordan's stagnant economy, high unemployment, and lack of resources.

Under the European Union (EU)-Jordan Compact, Jordan agreed to provide refugee employment in exchange for EU aid and the relaxation of the requirements for exporting to EU markets. Respondents observed, however, that the nature of the Jordanian economy-predominantly informal and largely dependent on the public sector and armed forces-makes refugee employment an unlikely reality:

The official figures of more than 100,000 work permits should not be taken as the reality; most of them are inactive. It was a condition imposed by the international community within the Brussels conference and the Jordan Compact, but it's very difficult for the government to put that into place in an informal economy. A lot of Jordanians are working informally, they don't have a contract, they don't have social security, they don't pay taxes...how can you expect Syrians to have a better legal framework than the Jordanians? (interview 13-J13, network organization)

These examples from the Jordanian context show how national governments may use the humanitariandevelopment nexus to capitalize on the presence of refugees. The findings also illustrate how, irrespective of international agreements, refugee employment ultimately depends on the nature and state of host countries' economies. This challenges the usefulness of the concept of resilience, if narrowly defined as economic self-reliance.

\subsubsection{Lebanon}

In Lebanon, the government initially pursued a "policy of no-policy" (Nassar \& Stel, 2019), leaving it up to UNHCR to respond to the increasing number of Syrian refugees. When the Lebanese government eventually intervened, it did so by suspending UNHCR's refugee registration services in 2015 (Janmyr, 2018). Unlike Turkey and Jordan, Lebanon did not allow for the establishment of official refugee camps, a decision respondents felt was influenced by Lebanon's experience with the Palestinian refugee camps and their perceived role in the civil war (see also Turner, 2015).

Lebanese authorities have maintained a hostile refugee discourse, emphasizing the temporariness of 
refugees' stay and calling for their return to Syria. Moreover, it has actively created a restrictive environment to discourage refugees from remaining in Lebanon. Besides the prohibition of refugee employment, high fees for residency permits and ambiguous enforcement of fee waivers, curfews, illegal detentions, discrimination and exploitation, the government has publicly attacked international actors for assisting refugees. As one respondent pointed out: "Policymakers and ministers here will accuse anyone, humanitarian agencies, the UN, the international community, of wanting the refugees to stay and that this is why they are granting so much assistance" (interview 15-L2, UN agency). Another respondent illustrated:

There was a lot of momentum when the Russians proposed a plan for returning refugees. The Lebanese media and politicians created a real hype because everybody wants the refugees to go back. We spoke out against it and said that it's not safe to go back. UNHCR got hit over the head by the foreign minister, and this is why they are still struggling to renew the residence permits of their staff. (interview 16-L3, INGO)

Respondents noted resistance from the Lebanese government to the idea of resilience (see also Culbertson, Oliker, Baruch, \& Blum, 2016; Fakhoury, 2019). In light of Lebanese politicians' anti-refugee rhetoric, this is not surprising, given the conceptualization of resilience as refugees' economic self-reliance, which necessitates access to employment opportunities. In turn, the government anticipates that refugees' employment would facilitate their integration into Lebanese society rather than encourage return to Syria. One respondent suggested that:

They didn't want to use the 3RP terminology, they used stabilization instead. I don't know what the issue of the government with resilience was, I think it was too long-term or something like that. So, they used stabilization. But I think even that has worn out because everybody has been overtaken by the reality that this is just a protracted crisis. (interview 16-L3, INGO)

What this will mean for Lebanon, which besides the refugee crisis is struggling with political instability, high unemployment, and more recently, widespread protests against corruption, economic collapse, and the outbreak of Covid-19, remains unclear. The Lebanese context clearly shows how host country politics characterized by hostility and resistance restrict the space for 'resiliencebuilding' programmes. The findings underline the crucial role of CSOs to navigate the political context and find ways to prevent refugees and host communities from becoming increasingly vulnerable.

Together, these examples show that, within the context of the 3RP, 'resilience,' defined in 3RP documenta- tion as the ability to "anticipate, withstand, recover and transform from shocks and crises" (3RP, 2019, p. 9), narrowly translates into a focus on economic self-reliance at the individual level, and as crisis management capacities at the state level. Justified by practitioners' understanding of the needs and the context, this interpretation of resilience is put into practice by linking humanitarian and development assistance, as well as engaging in practices of 'localization.' Ultimately, however, what the concept of resilience can achieve on the ground is constrained by the structural challenges inherent to the political and economic context, especially the relations between international actors on the one hand, and Turkish, Jordanian, Lebanese, or Syrian actors on the other.

\section{Discussion}

This study finds that practitioners associate 'resilience' predominantly with 'self-reliance,' echoing earlier findings by, for example, Aldunce et al. (2015). Conceptualized as economic self-reliance, moreover, resilience mirrors the neoliberal tendencies in established refugee self-reliance discourses, which portray the ideal refugee as an entrepreneur with "the skills, capacity and agency to stand on their own and sustain themselves without depending on external humanitarian aid" (Easton-Calabria \& Omata, 2018, pp. 1458-1459). As Easton-Calabria and Omata (2018) note, however, "employment opportunities do not necessarily lead to refugee self-reliance, nor are they alone a remedy for protracted situations" (p. 1459).

The examples from Turkey, Jordan, and Lebanon illustrate that refugees' access to employment opportunities hinges on host countries' willingness to provide the necessary enabling environment (Easton-Calabria \& Omata, 2018; Krause \& Schmidt, 2020). Resilienceprogramming, in the form of "market-based skills training and employability, income generation opportunities and entrepreneurship programmes" (3RP, 2019, p. 9) is a farce in the face of poor host economies and hostile political environments. Moreover, the reality of refugee employment is often defined by exploitation, vulnerability, and discrimination (Mencutek \& Nashwan, 2019)unlikely antecedents of either self-reliance or resilience. Nonetheless, the focus on access to jobs seems firmly entrenched within contemporary refugee governance (UNDP, International Labour Organization, \& World Food Programme, 2017).

Despite the convergence of their meanings as practitioners understand them, resilience and self-reliance are not the same things. As Krause and Schmidt (2020) point out, "self-reliance mainly suggests that refugees can support themselves, [whereas] resilience indicates their broader ability to absorb and deal with difficult situations and crises" (p. 23). Rather than a similarity to selfreliance or self-reliance as a constitutive element, theoretical explorations of resilience instead point to the importance of social networks and interdependencies 
(Aldrich \& Meyer, 2015). This demands inquiry into the motives behind the coalescence of resilience and selfreliance discourses in practice, even more so in the light of indications that self-reliance discourses have been used to justify the reduction of assistance (Hunter, 2009).

This study also finds that practitioners understand resilience-building as strengthening refugee-hosting states' capacities to manage the impact of the Syria crisis-particularly the pressure created by increased demand for public services. Inasmuch as Turkish, Jordanian, Lebanese, and Syrian-led CSOs are largely excluded by virtue of the very structure of the international crisis response system, 'localization' is narrowly translated to 'nationalisation.' Critical analyses of the localization agenda within humanitarian and development assistance have already called into question the local-international binary that "results in blind spots in the analysis of exclusionary practices of humanitarian action" (Roepstorff, 2020, p. 285).

On the one hand, emphasis on the responsibility of the governments of Turkey, Jordan, and Lebanonunder the header of 'localization' or 'local ownership' diverts attention away from the responsibility of the international community to ensure more equal burdensharing. Elsewhere, I have argued that under the guise of resilience, the EU pursues a refugee-containment strategy that risks the further destabilization of Jordan and Lebanon rather than "build their resilience" (Anholt \& Sinatti, 2020). On the other hand, nationalisation risks legitimizing what Tsourapas (2019) has described as "refugee rentiering." He argues that Turkey, Jordan, and Lebanon have employed "their position as host states of forcibly displaced populations to extract revenue, or refugee rent, from other state or non-state actors" (Tsourapas, 2019, p. 465). In this way, 'resiliencebuilding' may be a win-win for refugee-hosting states and donor governments wishing to keep refugee populations outside their borders, but a lose-lose situation for refugees.

\section{Conclusions}

This article has examined how the concept of resilience is translated into practice. Findings from interviews with humanitarian and development practitioners working in the context of the 3RP in Turkey, Jordan, and Lebanon illustrate how resilience takes on the meaning of selfreliance as it travels from the global to the local, and from policy to practice. Above all, the findings demonstrate the power of the political and economic context to restrict the agential capacities of 'translators,' revealing the limits of what policy buzzwords can achieve on the ground.

For policymakers and practitioners, continuous critical reflection on the interests and agendas that inform context-specific interpretations of resilience and whether 'resilience-building' programmes and operational practices actually improve the ability of systems and vulnerable populations to recover from a crisis is paramount. For resilience scholars, the next step is the in-depth examination of the-possibly conflictingvarieties of resilience that are likely to exist within and across different contexts, how these translate into divergent practices, and what impact these have on the ground.

\section{Acknowledgments}

I am grateful to the humanitarian and development professionals interviewed for this study for taking the time to share their thoughts and experiences with me in between the everyday hustle and bustle of aid work in the Middle East. My thanks extend to the guest editors of this thematic issue and the four anonymous reviewers for their comprehensive and thoughtful feedback, as well as to my colleagues from the Department of Political Science and Public Administration, Vrije Universiteit Amsterdam, for their valuable comments on earlier versions of this article.

\section{Conflict of Interests}

The author declares no conflict of interests.

\section{References}

Aldrich, D. P., \& Meyer, M. A. (2015). Social capital and community resilience. American Behavioral Scientist, 59(2), 254-269. https://doi.org/10.1177/ 0002764214550299

Aldunce, P., Beilin, R., Howden, M., \& Handmer, J. (2015). Resilience for disaster risk management in a changing climate: Practitioners' frames and practices. Global Environmental Change, 30, 1-11. https://doi.org/ 10.1016/j.gloenvcha.2014.10.010

Alexander, D. E. (2013). Resilience and disaster risk reduction: An etymological journey. Natural Hazards and Earth Systems Sciences, 13(11), 2707-2716. https:// doi.org/10.5194/nhess-13-2707-2013

Anholt, R., \& Sinatti, G. (2020). Under the guise of resilience: The EU approach to migration and forced displacement in Jordan and Lebanon. Contemporary Security Policy, 41(2), 311-335. https://doi.org/ 10.1080/13523260.2019.1698182

Arar, R. (2017). The new grand compromise: How Syrian refugees changed the stakes in the global refugee assistance regime. Middle East Law and Governance, 9(3), 298-312. https://doi.org/10.1163/1876337500903007

Béland, D., \& Ridde, V. (2016). Ideas and policy implementation: Understanding the resistance against free health care in Africa. Global Health Governance, 10(3), 9-23.

Bourbeau, P. (2018). On resilience: Genealogy, logics, and world politics. Cambridge: Cambridge University Press. 
Boztaş, Ö. (2019). Shrinking humanitarian space in Turkey: The government of Turkey's agency in shaping the operations of humanitarian NGOs in Turkey. METU Studies in Development, 46(2), 153-174.

Braun, A., Ball, S. J., Maguire, M., \& Hoskins, K. (2011). Taking context seriously: Towards explaining policy enactments in the secondary school. Discourse: Studies in the Cultural Politics of Education, 32(4), 585-596. https://doi.org/10.1080/01596306. 2011.601555

Braun, V., \& Clarke, V. (2006). Using thematic analysis in psychology. Qualitative Research in Psychology, 3(2), 77-101. https://doi.org/10.1191/ 1478088706qp063oa

Braun, A., Maguire, M., \& Ball, S. J. (2010). Policy enactments in the UK secondary school: Examining policy, practice and school positioning. Journal of Education Policy, 25(4), 547-560. https://doi.org/10.1080/ 02680931003698544

Chandler, D., \& Reid, J. (2016). The neoliberal subject: Resilience, adaptation and vulnerability. London: Rowman \& Littlefield International.

Clark, W. C., \& Swain, H. (1975). Hypotheticality, resilience and option foreclosure: Summary notes of a IIASA workshop. Laxenburg: International Institute for Applied Systems Analysis. Retrieved from http:// pure.iiasa.ac.at/id/eprint/348/1/WP-75-080.pdf

Clarke, J., Bainton, D., Lendvai, N., \& Stubbs, P. (2015). Making policy move: Towards a politics of translation and assemblage. Bristol: Policy Press.

Comfort, L. K., Boin, A., \& Demchak, C. C. (2010). Designing resilience: Preparing for extreme events. Pittsburgh, PA: University of Pittsburgh Press.

Cornwall, A., \& Brock, K. (2005). What do buzzwords do for development policy? A critical look at "participation", "empowerment" and "poverty reduction". Third World Quarterly, 26, 1043-1060. https://doi. org/10.1080/01436590500235603

Culbertson, S., Oliker, O., Baruch, B., \& Blum, I. (2016). Rethinking coordination of services to refugees in urban areas: Managing the crisis in Jordan and Lebanon. Santa Monica, CA: Rand Corporation. Retrieved from https://www.rand.org/content/ dam/rand/pubs/research_reports/RR1400/RR1485/ RAND_RR1485.pdf

Cupolo, D. (2017, April 27). Turkey steps up crackdown on humanitarian aid groups. The New Humanitarian. Retrieved from http://www.thenewhumanitarian. org/news/2017/04/27/turkey-steps-crackdownhumanitarian-aid-groups

Czarniawska, B., \& Sevón, G. (2005). Translation is a vehicle, imitation its motor, and fashion sits at the wheel. In B. Czarniawska \& G. Sevón (Eds.), Global ideas: How ideas, objects and practices travel in the global economy (pp. 7-12). Malmö: Liber \& Copenhagen Business School Press.

Dionigi, F. (2016). The Syrian refugee crisis in Lebanon: State fragility and social resilience. London: LSE
Middle East Centre. Retrieved from http://eprints. Ise.ac.uk/65565/1/Dionigi_Syrian_Refugees\%20in \%20Lebanon_Author_2016.pdf

Duffield, M. (2012). Challenging environments: Danger, resilience and the aid industry. Security Dialogue, 43(5), 475-92. https://doi.org/10.1177/ 0967010612457975

Easton-Calabria, E., \& Omata, N. (2018). Panacea for the refugee crisis? Rethinking the promotion of 'selfreliance' for refugees. Third World Quarterly, 39(8), 1458-1474. https://doi.org/10.1080/01436597. 2018.1458301

Evans, B., \& Reid, J. (2013). Dangerously exposed: The life and death of the resilient subject. Resilience: International Policies, Practices and Discourses, 1(2), 83-98. https://doi.org/10.1080/21693293.2013.770703

Evans, B., \& Reid, J. (2014). Resilient life: The art of living dangerously. Cambridge: Polity Press.

Fakhoury, T. (2019, July 5). Contested meanings of resilience building: How great expectations in Brussels are dashed in Beirut. London School of Economics and Political Science Middle East Centre Blog. Retrieved from https://blogs.Ise.ac.uk/mec/2019/ 07/05/contested-meanings-of-resilience-buildinghow-great-expectations-in-brussels-are-dashed-inbeirut

Field, J. (2016). 'No voice can be heard above the gunfire': Protection, partnerships and politicking in the Syrian Civil War. In F. Espada (Ed.), Essays on humanitarian effectiveness (pp. 157-195). London: Humanitarian Affairs Team and Humanitarian and Conflict Response Institute.

Fischer, F., \& Gottweis, H. (Eds.). (2012). The argumentative turn revisited: Public policy as communicative practice. Durham, NC: Duke University Press.

Freeman, R. (2009). What is 'translation'? Evidence \& Policy, 5(4), 429-447. https://doi.org/10.1332/ $174426409 \times 478770$

Gonzalez, G. (2016). New aid architecture and resilience building around the Syria crisis. Forced Migration Review, 52, 26-28.

Hawks, F. L. (1856). Narrative of the expedition of an American squadron to the China seas and Japan, performed in the years 1852, 1853, and 1854, under the command of Commodore M. C. Perry, United States Navy, by order of the Government of the United States. Washington, DC: Beverly Tucker, Senate Printer. Retrieved from https://archive.org/details/ narrativeofexped0156perr/page/n5

Hilhorst, D. (Ed.). (2013). Disaster, conflict and society in crises: Everyday politics of crisis response. Abingdon: Routledge.

Hilhorst, D. (2018). Classical humanitarianism and resilience humanitarianism: Making sense of two brands of humanitarian action. Journal of International Humanitarian Action, 3. https://doi.org/10.1186/ s41018-018-0043-6

Holling, C. S. (1973). Resilience and stability of ecologi- 
cal systems. Annual Review of Ecology and Systematics, 4(1), 1-23. https://doi.org/10.1146/annurev.es. 04.110173 .000245

Hunter, M. (2009). The failure of self-reliance in refugee settlements. POLIS Journal, 2, 1-46. Retrieved from https://pdfs.semanticscholar.org/6ca6/61d95 d08e420246bdb9c1084f83cb9dfd331.pdf

Ilcan, S., \& Rygiel, K. (2015). "Resiliency humanitarianism": Responsibilizing refugees through humanitarian emergency governance in the camp. International Political Sociology, 9, 333-351. https://doi.org/ 10.1111/ips.12101

Janmyr, M. (2018). UNHCR and the Syrian refugee response: Negotiating status and registration in Lebanon. The International Journal of Human Rights, 22, 393-419. https://doi.org/10.1080/ 13642987.2017 .1371140

Kelberer, V. (2017). Negotiating crisis: International aid and refugee policy in Jordan. Middle East Policy, 24(4), 148-165. https://doi.org/10.1111/mepo. 12313

Krause, U., \& Schmidt, H. (2020). Refugees as actors? Critical reflections on global refugee policies on selfreliance and resilience. Journal of Refugee Studies, 33(1), 22-41. https://doi.org/10.1093/jrs/fez059

Lentzos, F., \& Rose, N. (2009). Governing insecurity: Contingency planning, protection, resilience. Economy and Society, 38(2), 230-254. https://doi.org/ $10.1080 / 03085140902786611$

Manyena, S. B. (2006). The concept of resilience revisited. Disasters, 30(4), 434-450. https://doi.org/10.1111/ j.0361-3666.2006.00331.x

Masten, A. S. (2013). Risk and resilience in development. In P. D. Zelazo (Ed.), Oxford handbook of developmental psychology: Vol. 2-Self and other (pp. 579-607). New York, NY: Oxford University Press.

Masten, A. S. (2018). Resilience theory and research on children and families: Past, present, and promise. Journal of Family Theory \& Review, 10, 12-31. https://doi.org/10.1111/jftr.12255

Mellen, R., \& Lynch, C. (2017, August 3). Inside Turkey's NGO purge. Foreign Policy. Retrieved from https:// foreignpolicy.com/2017/08/03/inside-turkeys-ngopurge

Mencutek, Z. S., \& Nashwan, A. J. (2019). Perceptions about the labour market integration of refugees: Evidences from Syrian refugees in Jordan. Journal of International Migration and Integration, 2020. https://doi.org/10.1007/s12134-020-00756-3

Mukhtarov, F. (2014). Rethinking the travel of ideas: Policy translation in the water sector. Policy \& Politics, 42(1), 71-88. https://doi.org/10.1332/ $030557312 \times 655459$

Nassar, J., \& Stel, N. (2019). Lebanon's response to the Syrian refugee crisis: Institutional ambiguity as a governance strategy. Political Geography, 70, 44-54. https://doi.org/10.1016/j.polgeo.2019.01.005

Neumann, B., \& Nünning, A. (2012). Travelling concepts as a model for the study of culture. In B. Neumann \& A. Nünning (Eds.), Travelling concepts for the study of culture (pp. 1-22). Berlin: Walter de Gruyter.

Neumann, B., \& Tygstrup, F. (2009). Travelling concepts in English studies. European Journal of English Studies, 13(1), 1-12. https://doi.org/10.1080/1382 5570802708113

O’Malley, P. (2010). Resilient subjects: Uncertainty, warfare and liberalism. Economy and Society, 39(4), 488-509. https://doi.org/10.1080/03085147. 2010.510681

Powell, W. W., Gammal, D. L., \& Simard, C. (2005). Close encounters: The circulation and reception of managerial practices in the San Francisco Bay area nonprofit community. In B. Czarniawska \& G. Sevón (Eds.), Global ideas: How ideas, objects and practices travel in the global economy (pp. 233-258). Malmö: Liber \& Copenhagen Business School Press.

Regional Refugee and Resilience Plan. (2014). Regional refugee \& resilience plan 2015-2016 in response to the Syria crisis: Regional strategic overview. Geneva and New York, NY: UNHCR and UNDP. Retrieved from https://reliefweb.int/sites/reliefweb. int/files/resources/3RP-Report-Overview.pdf

Regional Refugee and Resilience Plan. (2019). Regional strategic overview 2020-2021. Geneva and New York, NY: UNHCR and UNDP. Retrieved from http://www.3rpsyriacrisis.org/wp-content/uploads/ 2020/04/rso_150dpi.pdf

Roepstorff, K. (2020). A call for critical reflection on the localisation agenda in humanitarian action. Third World Quarterly, 41(2), 284-301. https://doi.org/ 10.1080/01436597.2019.1644160

Scott-Smith, T. (2018). Paradoxes of resilience: A review of the World Disasters Report 2016. Development and Change, 49(2), 662-677. https://doi.org/ 10.1111/dech.12384

Terry, G., Hayfield, N., Clarke, V., \& Braun, V. (2017). Thematic analysis. In C. Willig \& W. Stainton-Rogers (Eds.), The Sage handbook of qualitative research in psychology (2nd ed., pp. 17-37). London: SAGE.

Tsourapas, G. (2019). The Syrian refugee crisis and foreign policy decision-making in Jordan, Lebanon, and Turkey. Journal of Global Security Studies, 4(1), 464-481. https://doi.org/10.1093/jogss/ogz016

Turner, L. (2015). Explaining the (non-)encampment of Syrian refugees: Security, class and the labour market in Lebanon and Jordan. Mediterranean Politics, 20(3), 386-404. https://doi.org/10.1080/13629395. 2015.1078125

United Nations Development Programme. (2014). A resilience-based development response to the Syria crisis. Amman: United Nations Development Programme. Retrieved from http://www.undp.org/ content/dam/rbas/doc/SyriaResponse/A\% 20resilience-based\%20development\%20response\% 20to\%20the\%20Syria\%20crisis.pdf

United Nations Development Programme, International 
Labour Organization, \& World Food Programme. (2017). Jobs make the difference: Expanding economic opportunities for Syrian refugees and host communities. New York, NY, Geneva, and Rome: United Nations Development Programme, International Labour Organization, and World Food Programme. Retrieved from https://reliefweb.int/ sites/reliefweb.int/files/resources/compressed_ 12312313123UNDP_JOR_FINAL_Low\%2520Res.pdf

United Nations High Commissioner for Refugees. (2012). Syria regional response plan. Geneva: United Nations High Commissioner for Refugees. Retrieved from https://reliefweb.int/sites/reliefweb.int/files/ resources/SyriaRRP.pdf

United Nations Office for the Coordination of Humanitarian Affairs. (2017). The new way of working. New York, NY, and Geneva: United Nations Office for the Coordination of Humanitarian Affairs. Retrieved from https://www.unocha.org/sites/unocha/files/ NWOW\%20Booklet\%20low\%20res.002_0.pdf

Walker, B., Holling, C. S., Carpenter, S. R., \& Kinzig, A.
(2004). Resilience, adaptability and transformability in social-ecological systems. Ecology and Society, 9(2). Retrieved from https://www.jstor.org/stable/ $10.2307 / 26267673$

Weichselgartner, J., \& Kelman, I. (2014). Geographies of resilience: Challenges and opportunities of a descriptive concept. Progress in Human Geography, 39(3), 249-267. https://doi.org/10.1177/ 0309132513518834

Weisser, F., Bollig, M., Doevenspeck, M., \& Müller-Mahn, D. (2014). Translating the 'adaptation to climate change' paradigm: The politics of a travelling idea in Africa. The Geographical Journal, 180(2), 111-119. https://doi.org/10.1111/geoj.12037

Wildavsky, A. B. (1988). Searching for safety. Abingdon: Routledge.

Zetter, R. (2020). From humanitarianism to development: Reconfiguring the international refugee response regime. In T. Bastia \& R. Skeldon (Eds.), Routledge handbook of migration and development (pp. 353-362). Abingdon: Routledge.

\section{About the Author}

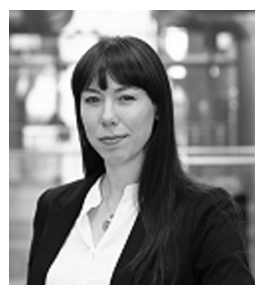

Rosanne Anholt is Assistant Professor at the Department of Political Science and Public Administration, Vrije Universiteit Amsterdam. Her research looks at how the policy buzzword of resilience is used in EU security, humanitarian, and development policy, as well as how it is understood and used in practice in the context of responding to the impact of the Syria crisis in Jordan, Lebanon, and Turkey. Rosanne's research interests include humanitarian aid and development assistance, international crisis governance, and the (dis)connections between policy and practice. 